\title{
Excess Reserve Holdings of Jordan Commercial Banks: VARX Implementation
}

\author{
Ahmad Y. Khasawneh ${ }^{1}$ \\ ${ }^{1}$ Faculty of Economics and Administrative Sciences, Hashemite University, Zarqa, Jordan \\ Correspondence: Ahmad Y. Khasawneh, Department of Finance, Faculty of Economics and Administrative \\ Sciences, Hashemite University, Zarqa, Jordan. E-mail: ahmadk@hu.edu.jo
}

Received: September 10, 2013

Accepted: October 2, 2013

Online Published: October 26, 2013

doi:10.5539/ijef.v5n11p152

URL: http://dx.doi.org/10.5539/ijef.v5n11p152

\begin{abstract}
This study tends to fill a gap in the literature as it considers a small open developing country in a region that takes the attention of the world. The main aim of this study is to examine the factors that determine commercial banks excess reserve holdings in Jordan banking system. Vector Autoregressive with explanatory variables (VARX) technique is used. The empirical results suggest that excess reserve in Jordan banking system tend to reach its long term level after four quarters and the correction process occurs every six months. Another finding, as banks customers' prefer to hold currency banks prefer to hold less excess reserve. Moreover, banks tend to hold more excess reserve in booming economies. Finally, monetary policy tools seem to be affecting factors in banks excess reserve holding preferences. However, fiscal policy does not seem to be within the factors that affect excess reserve holdings.
\end{abstract}

Keywords: excess reserve, jordan commercial banks, monetary policy, var, varx

\section{Introduction}

\subsection{Research Problem and Importance}

Central banks supervise and control banks using direct and indirect tools in order to achieve stability in prices, keep interest rate in the desired level, and stabilize exchange rate in country currency. On the other hand, Banks hold reserve with central bank in order to meet their liabilities. The main objective that monetary authority controlling and supervising commercial banks is to limit their daily transaction and to make sure that commercial banks do not extend the granting facilities, because unreasonable increase in lending leads to high inflation which on the other hand causes a shortage in banks' liquidity. Banks usually has two types of reserve, one is obligatory required by central banks and another is optional. The excess reserve is the deposited amount into a central bank account that exceeds the required reserve. The required reserve usually earns no interest while the excess reserve may earn little or no interest.

Central bank of Jordan (CBJ) is the monetary authority that takes the responsibility to monitor and supervise the banking system in Jordan, which was established in 1964 and officially started in 1965. Like all banking system in the world, CBJ has imposed the required reserve on banks various types of deposits in 1967 in order to control banks when monetary policy implemented and to provide liquidity when shortage occurs. Required reserve is imposed on commercial bank deposits, the ratio of required reserve changes according to monetary policy objectives. CBJ should hold at least 5\% of the bank's deposits and not more than $35 \%$ (Note 1).

According to the CBJ standards, the excess reserves of commercial banks includes reserves on: net issue of governments security that issued by the Ministry of Finance plus the interest rate that accrued on this issues, the amount of banks borrowing from each other, certificate of deposits (CD) which is issued by CBJ as direct tool to absorbing liquidity, repurchase agreement between banks (overnight Repo), and the window amount (what left from banks reserves at the end of daily transaction) (Note 2).

The objective of this study is to analyze the excess reserve holding in Jordan banking system and to investigate the determinants of commercial banks excess reserve holding. It also aims to estimate the marginal effect of each of the determinants of banks' excess reserve holding. In order to achieve the purpose of this study and following previous researchers time series techniques are employed.

The importance of this study comes from the timing of its investigation as the sample considers observations that 
cover the period before and after the 2006/2007 financial crises. Moreover, it considers Jordan banking system which is a Middle Eastern country that is surrounded with political conflicts. To my knowledge, there is no previous study covers similar country in similar region during the financial crises. Therefore this study tends to fill a gap in the literature as it considers a small open developing country in a region that takes the attention of the world.

The rest of the study is organized as follows; the next section provide a brief review of the literature, section three describes each type of reserves in Jordan banking system and their implementation trend. Section four explains specifications of empirical models and variables definitions, source of data and sample selection follows in section five. The following section introduces the empirical results and section seven concludes.

\subsection{Literature Review}

Due to the importance of excess reserve in the banking system continuous research studies were performed to investigate the factors that determine why profit maximizing banks hold excess reserve. The literature in the topic is divided into two groups, a group of literature focus on developing reserve management models (Orr \& Mellon, 1961; Poole, 1968; Frost, 1971; Baltensperger, 1974; Baltensperger, 1980; Santomero, 1984, Longworth, 1989). More recently, other studies continue to modeling banks' reserve management (Civcir \& Parikh 1998; Allen, 1998; Nautz, 1998; Furfine, 1998; Clouse \& Dow, 1999; Selgin, 2001; Clouse \& Dow, 2002; Heller \& Lengwiler, 2003; and Bindseil, Camba-Mendez, Hinch, \& Weller, 2004). On the other hand, literature body has a set of studies that empirically investigate commercial banks' demand for excess reserve (Agenor, Aizenman, \& Hoffmaister, 2004; Demiralp \& Farley, 2005; Maynard \& Moore, 2005; Aikaeli, 2006; Saxegaard, 2006; Murta \& Garcia, 2009; Agenor \& El Aynaoui, 2010; Talasli, 2010; Anderson-Reid, 2011).

A brief explanation of some of the studies which are related to the determinants of excess reserve is introduced. Agenor et. al. (2004) develop a model that sets the precautionary motives as the determinants of excess liquid assets held by commercial banks. They include the required reserve ratio to total deposits, uncertainty in the ratio in cash to deposit, the dispersion of output from trend, the discount rate and the lag of excess reserve. Their work was extended by Saxegaard (2006) by including variables that account for the unintentional build-up of excess reserves using a sample data set from the banking system in sub-Saharan Africa (SSA). Saxegaard commented that banks tend to hold higher excess reserve to protect them against surprising deposits withdrawals. Moreover, he includes the demand deposits to time and savings deposits ratio and find that this variable has a positive impact on the excess reserve holdings.

Another study by Demiralp \& Farley (2005) investigates the determinants of reserves and the impact of monetary policy tools on these factors. Their model includes required reserve ratio, an important tool of monetary policy, as an influencing factors on excess reserve. Their investigation also considers change in average daily reserve maintenance, the federal rate, open market operations and the amount of required for each bank. The main conclusion of suggest a positive impact of open market operations on excess reserve. The determinants of demand for excess liquid assets in Barbados banking system during the period of $1974-2004$ are investigated by Maynard \& Moore (2005). Their empirical results classify the determinants of excess reserve demand into customer characteristics, economic condition, monetary policies and fiscal policies. Maynard \& Moore include the net domestic assets of central bank to account for the effect of fiscal policies. Their findings suggest a positive relationship between cash to deposit ratio, the customers' preferences variable. They also find a significant impact of the monetary measures on the demand for excess reserve. Economics condition and fiscal policy tools are also concluded to affect the level of excess reserve, according to Maynard \& Moore.

Aikaeli (2006) investigates the long run determinants of excess reserve holdings. His study finds a negative long run effect of required reserve on excess reserve and positive long run effect of cash preferences, bank borrowing rate, and loan return variation on excess reserve bank holdings. Murta \& Garcia (2009) discuss that banks hold reserve to manage their liquidity risk. They employ a sample from the banking system in the EURO area to investigate the demand for excess reserve. Their main findings suggest that there is a positive impact of financing cost on excess reserve demand. Moreover, there is no significant impact of uncertainty resulted from the credit crisis on the demand for excess reserve.

Agenor \& El Aynaoui (2010) use a simple macroeconomic model with credit market imperfection and find that demand for excess reserve is determined by precautionary variables and the forgone opportunity from holding the reserve. Talasli (2010) investigates the determinants of excess reserve demand in Turkey banking system and analyze the pattern of reserve holding in Turkey using ARMA based model. He concludes that there is a systematic pattern of excess reserve balances within single maintenance period. Moreover, liquidity shocks, size of outflow funds and shortage in interbank borrowing have significant effect on the pattern of holding excess 
reserve.

Anderson-Reid (2011) examines the determinants of demand for excess reserves in the banking system of Jamaica during the period of 1998:Q1- 2010:Q4. His conclusions are consistent with Agenor et. al. (2004). Anderson-Reid argues that there is positive short run effect of required reserve on excess reserves demand while there is no significant long run impact of required reserve on the demand for excess reserve. Furthermore, his findings suggest a positive effect of government securities and output volatility on excess reserves demand, and a negative effect of currency to deposit ratio on the demand for excess reserves.

\subsection{Facts about Monetary System in Jordan}

Financial crises threatening the financial stability in Jordanian banking system which let the CBJ faces many challenges. CBJ intervenes by adopting expansionary monetary policy that helps banks to have more liquidity to face the impact of crisis. Tools of monetary policy include required reserve, Discount rate and open market. However the main tool that CBJ use to control money supply in the market is required reserve ratio.

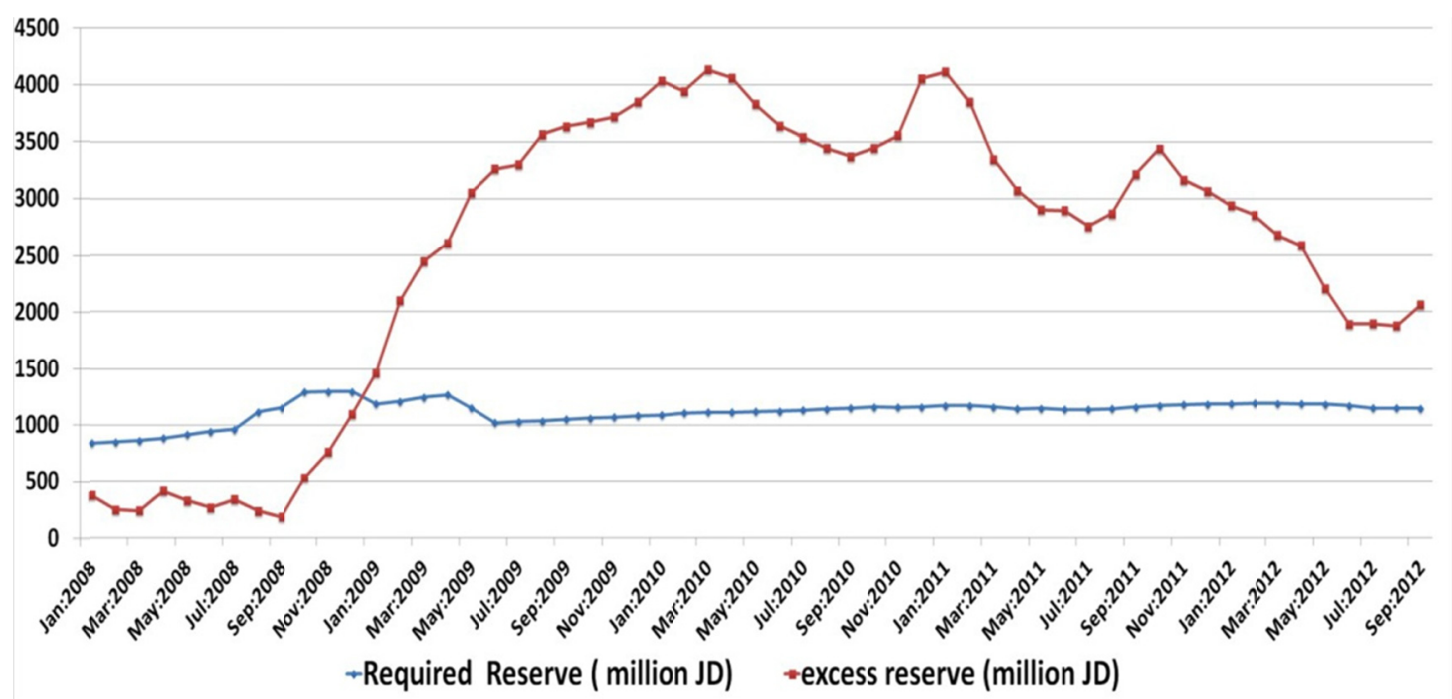

Figure 1. Excess and required reserve during (Jan 2008-Sep 2012)

The plot above shows the trend of both excess and required reserve in Jordanian banking system. During the year of 2008 required reserve is above excess reserve that is due to the deposits withdrawals as banks customers reduced the confidence in Jordan banking system as a result to world financial crises in addition to a relatively high required reserve ratio during that year as it was around $10 \%$. Adopting an expansionary monetary policy by the CBJ to face the financial crises led to several reduction of the required reserve ratio as it has reached $7 \%$ on May 2009. After the beginning of year 2009 the excess reserve has started growing again as banks system has regained customers' confidence in addition that required reserve ratio has been almost constant. The average excess reserve reached JD2058 million at the end of Sep 2012 while required reserve averaged JD1148 million JD at the same period. Figure (2) present another important issue in the banking system as it present the interbank borrowing volume and rate. Banks require reserve for their daily transaction and if they face shortage in this amount they borrow from each other to fill up the shortage in their liquidity. A relationship is obvious between excess and interbank borrowing volume, during year 2008 when the excess reserve was low the interbank borrowing was high and the interbank borrowing rate was high. After 2009 the interbank borrowing rate has reduced and the interbank market became active. 


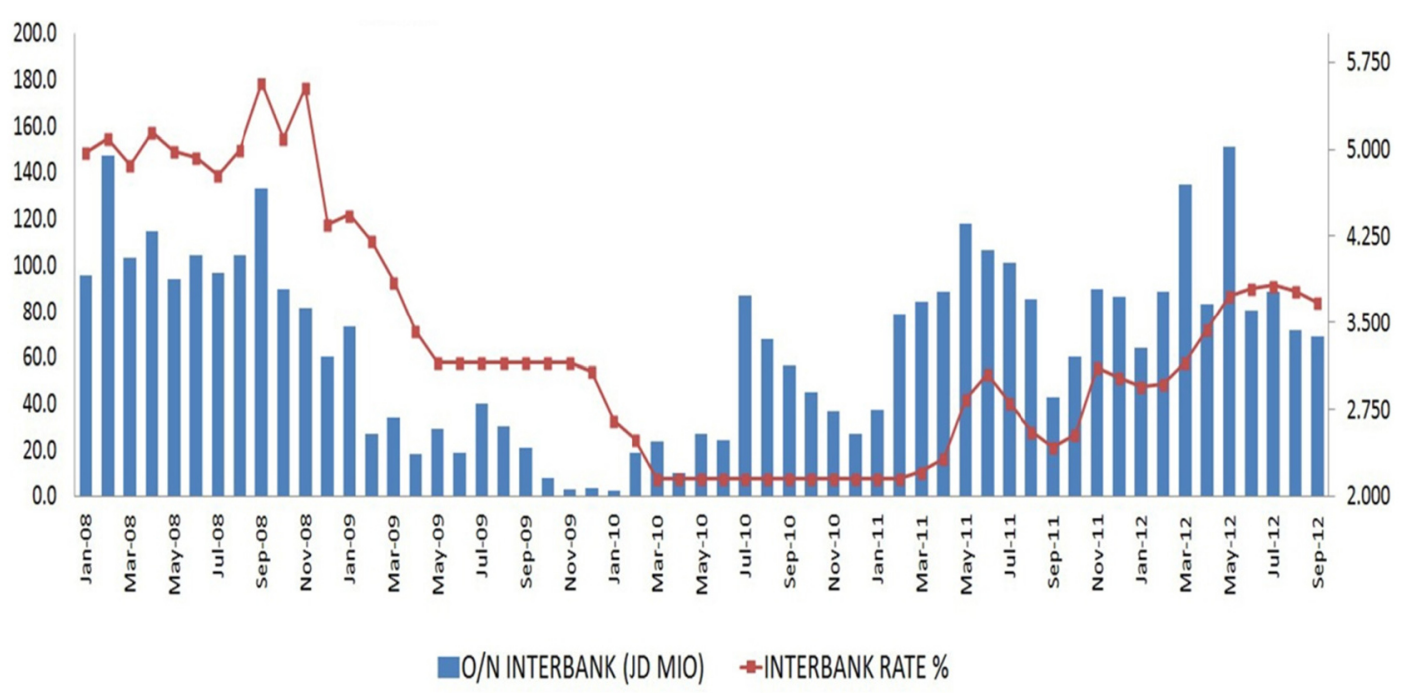

Figure 2. Interbank between banks system during (Jan 2008-Sep 2012)

Another monetary policy tool is OMO which inject liquidity to the market. Figure (3) indicates that excess reserve and OMO move in the same direction. When CBJ purchase securities from commercial banks it will increase the excess reserve in the banking system. OMO can be of two types; outright securities and repo transactions. Which affect excess reserve in different way, outright securities have permanent effect on excess reserve for banks system because commercial banks sell securities permanently to CBJ, while repo transaction has temporarily effect on excess reserve because when CBJ purchase securities inject more liquidity in the banking system and it is temporarily because banks are given the right to buy the securities back in certain time at higher rate.

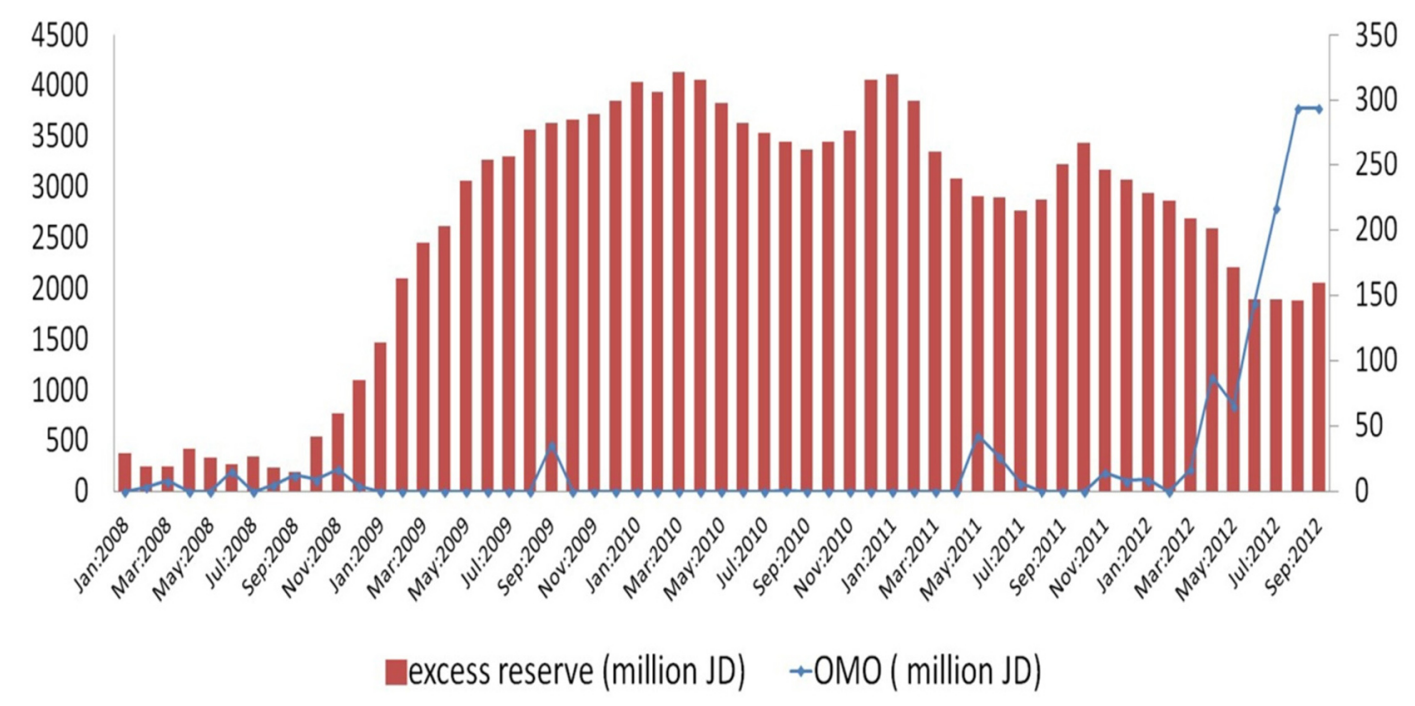

Figure 3. Excess reserve \& OMO during (Jan 2008-Sep 2012)

\section{Method and Data}

\section{I Empirical Model}

The literature in the topic of excess reserve demand specifies the factors that affect the demand of commercial banks for excess reserve according to the reasons behind holding these reserves. Commercial banks hold excess reserve to avoid central banks penalties on overdraft. Therefore, factors determine the excess reserve demand are set into four groups; banks characteristics, economic condition, monetary policy and fiscal policy (Dow, 2001; Agenor et.al., 2004; Maynard \& Moore, 2005; Demiralp \& Farley, 2005; Saxegaard, 2006; Anderson-Reid, 2011 
and others)

A modified version of Agenor et.al (2004) is adopted to estimate excess reserve demand elasticities as specified in equation 1.

$$
\begin{aligned}
& \ln \left(E R_{t}\right)=\varphi_{0}+\varphi_{1} \ln (C / D)_{t}+\varphi_{2} \ln \left(R G D P_{t}\right)+\varphi_{3} \ln \left(N D A_{t}\right) \\
& +\varphi_{4} \ln \left(R R_{t}\right)+\varphi_{5} \ln \left(R_{t}^{T B}\right)+\varphi_{6} \ln \left(R_{t}^{I B L}\right)+\varphi_{7} \ln \left(R_{t}^{O W D}\right)+\varepsilon_{t}
\end{aligned}
$$

The dependent variable is the amount of excess reserve held by commercial banks with the central bank. The first independent variable is the commercial banks customer characteristics measured by the currency to deposits $\operatorname{ratio}(C / D)$, this variable represents the ability of the bank to meet commercial banks' customer currency demand fluctuations (Anderson-Reid, 2011). The economic condition is measured by the real gross domestic product (RGDP) and is expected sign may be in both directions, positive and negative, it is positive as in boom condition the economic activities grows and banks will tend to hold more reserve to avoid any overdraft. It also can be negative as boom condition may increase the opportunity cost of holding none earning reserve and therefore will hold no reserve or less reserve.

Fiscal policy is measured by the net domestic assets of central banks assets (NDA), this variable proxy for the government spending and the tax policy in the economy. Expansionary fiscal policy implies higher NDA and thus higher excess reserve. Monetary policy is measured by required reserve (RR) and interest rates (interest rate on treasury bills and bonds $\left(\mathrm{R}^{\mathrm{TB}}\right)$, interest rate on interbank borrowing $\left(\mathrm{R}^{\mathrm{IBL}}\right)$ and interest rate on overnight window deposits $\left(\mathrm{R}^{\mathrm{OWD}}\right)$ ). The required reserve ratio is expected to negatively affect the excess reserve holding. When monetary authority increases $R R$ it is meant for the economy to slow down through reducing the percentage of deposits available for commercial banks for loans purposes. As a result the commercial banks will also lower their holding of excess reserve in order to compensate the reduction of loans. In other words, RR is expected to negatively affect the banks holding of ER.

The interest rate on the treasury bills can be viewed as the opportunity cost of holding excess reserve that is the higher the interest on treasury bills the higher the cost of holding excess reserve. Therefore, $\mathrm{R}^{\mathrm{TB}}$ is expected to negatively affect the holding of excess reserve. The interest rate on interbank loans $\left(\mathrm{R}^{\mathrm{IBL}}\right)$, interbank loans is the type of loans that commercial banks may refer to fund the financial deficiency. The $\left(\mathrm{R}^{\mathrm{IBL}}\right)$ is the cost of these loans hence the higher the $\left(\mathrm{R}^{\mathrm{IBL}}\right)$ the higher the cost of interbank loans. Therefore, the higher the $\left(\mathrm{R}^{\mathrm{IBL}}\right)$ is the higher the incentives for commercial banks to hold more ER and vise a versa. Finally, the overnight window deposit interest rate $\left(\mathrm{R}^{\mathrm{OWD}}\right)$ is included, there is a positive relationship expected between ER and ( $\left.\mathrm{R}^{\mathrm{OWD}}\right)$.

\subsection{Sample Selection and Data Sources}

Time series data sample for the dependent variable and independent variables is constructed for the period 1994-Q1 to 2012-Q4. The resulted sample contains 76 observations in quarterly frequency format. Table (1) provides some figures statistics to describe the nature of the sample set. The numbers in Table (1) show that all variables are close to their means (small standard deviation), that is observations of each variable series are close to normal distribution. The data set is sourced from central bank of Jordan publications and statistics - statistical database, available online on CBJ.

Table 1. Summary statistics of included variables

\begin{tabular}{cccccc}
\hline Variable & Obs & Mean & Std. Dev. & Min & Max \\
\hline LER & 76 & 5.29765 & 1.05411 & 2.11625 & 6.87088 \\
LCD & 76 & -1.66215 & 0.18505 & -3.05467 & -1.17855 \\
LRGDP & 76 & 7.26491 & 0.29797 & 6.77593 & 7.7488 \\
LNDA & 76 & 7.78456 & 1.81705 & -6.90775 & 8.57529 \\
LRR & 76 & 6.35615 & 0.45647 & 5.6458 & 7.16757 \\
LRTB & 76 & 2.35491 & 0.16909 & 2.02551 & 2.63691 \\
LRIBL & 76 & 1.33828 & 0.46513 & 0.02955 & 2.26902 \\
LROWD & 76 & 1.22692 & 0.47564 & -0.69314 & 2.25129 \\
\hline
\end{tabular}

The natural logarithm is taken to all variables included in the model. The variable of net domestic asset (NDA) has many negative values which make calculating the natural logarithm impossible. Therefore, before calculating the natural logarithm for the NDA variable mathematical transformation is done to all observations according to the following transformation equation $\mathrm{NDA}_{\mathrm{t}}=\mathrm{NDA}_{\mathrm{t}}-\mathrm{Min}\{\mathrm{NDA}\}$. 


\section{Discussion of Empirical Results}

\subsection{Estimations Results}

The nature of macroeconomic variables has high possibility of being trending and non-stationary. Therefore, it is necessary to perform unit root test to figure out the level of integration of each variable. I employ two unit root tests, Augmented Dickey Fuller (ADF) test and Phillips Perron (PP) test, Table (2) reports the results of unit root test employing three model specifications, with constant term, without constant term and with trend.

Table 2. Unit root test of model's variables

\begin{tabular}{|c|c|c|c|c|c|c|}
\hline \multirow[t]{2}{*}{ Test Models } & \multicolumn{3}{|c|}{ Augmented Dickey-Fuller } & \multicolumn{3}{|c|}{ Phillips - Perron } \\
\hline & LER & DLER & Result & LER & DLER & Result \\
\hline With Constant & -2.487 & $-12.673 *$ & $\mathrm{I}(1)$ & -2.091 & $-13.609^{*}$ & $\mathrm{I}(1)$ \\
\hline No constant & -0.065 & $-12.716^{*}$ & $\mathrm{I}(1)$ & 0.328 & $-13.598^{*}$ & $\mathrm{I}(1)$ \\
\hline \multirow[t]{2}{*}{ With trend } & $-5.502 *$ & $-12.585^{*}$ & $\mathrm{I}(0)$ & $-5.463 *$ & $-13.505^{*}$ & $\mathrm{I}(0)$ \\
\hline & LCD & DLCD & Result & LCD & DLCD & Result \\
\hline With Constant & -2.881 & $-10.356^{*}$ & $\mathrm{I}(1)$ & $-3.234^{*}$ & $-10.313 *$ & $\mathrm{I}(0)$ \\
\hline No constant & 1.651 & $-9.801 *$ & $\mathrm{I}(1)$ & 1.933 & $-9.731 *$ & $\mathrm{I}(1)$ \\
\hline \multirow[t]{2}{*}{ With trend } & -2.964 & $-10.797 *$ & $\mathrm{I}(1)$ & -2.853 & $-10.859 *$ & $\mathrm{I}(1)$ \\
\hline & LRGDP & DLRGDP & Result & LRGDP & DLRGDP & Result \\
\hline With Constant & -0.840 & $-8.952^{*}$ & $\mathrm{I}(1)$ & -0.146 & $-21.078^{*}$ & $\mathrm{I}(1)$ \\
\hline No constant & 1.752 & $-8.624 *$ & $\mathrm{I}(1)$ & $7.955^{*}$ & $-11.383^{*}$ & $\mathrm{I}(0)$ \\
\hline \multirow[t]{2}{*}{ With trend } & $-5.501^{*}$ & $-8.890^{*}$ & $\mathrm{I}(0)$ & $-5.173 *$ & $-20.834^{*}$ & $\mathrm{I}(0)$ \\
\hline & LNDA & DLNDA & Result & LNDA & DLNDA & Result \\
\hline With Constant & $-6.671^{*}$ & $-14.222 *$ & $\mathrm{I}(0)$ & $-6.795^{*}$ & $-18.762 *$ & $\mathrm{I}(0)$ \\
\hline No constant & -1.230 & $-14.320 *$ & $\mathrm{I}(1)$ & -0.731 & $-18.915 *$ & $\mathrm{I}(1)$ \\
\hline \multirow{2}{*}{ With trend } & $-7.534 *$ & $-14.128^{*}$ & $\mathrm{I}(0)$ & $-7.589 *$ & $-18.644 *$ & $\mathrm{I}(0)$ \\
\hline & LRR & DLRR & Result & LRR & DLRR & Result \\
\hline With Constant & -0.095 & $-6.848^{*}$ & $\mathrm{I}(1)$ & -0.335 & $-6.832 *$ & $\mathrm{I}(1)$ \\
\hline No constant & 1.599 & $-6.709 *$ & $\mathrm{I}(1)$ & 1.308 & $-6.698 *$ & $\mathrm{I}(1)$ \\
\hline \multirow[t]{2}{*}{ With trend } & -1.250 & $-6.861 *$ & $\mathrm{I}(1)$ & -1.427 & $-6.830 *$ & $\mathrm{I}(1)$ \\
\hline & LRTB & DLRTB & Result & LRTB & DLRTB & Result \\
\hline With Constant & -0.718 & $-8.225^{*}$ & $\mathrm{I}(1)$ & -0.810 & $-8.272 *$ & $\mathrm{I}(1)$ \\
\hline No constant & -0.644 & $-8.231 *$ & $\mathrm{I}(1)$ & -0.596 & $-8.281 *$ & $\mathrm{I}(1)$ \\
\hline \multirow[t]{2}{*}{ With trend } & -1.420 & $-8.161 *$ & I(1) & -1.551 & $-8.214 *$ & $\mathrm{I}(1)$ \\
\hline & LRIBL & DLRIBL & Result & LRIBL & DLRIBL & Result \\
\hline With Constant & $-4.623 *$ & $-12.056^{*}$ & $\mathrm{I}(0)$ & $-4.687 *$ & $-12.531^{*}$ & $\mathrm{I}(0)$ \\
\hline No constant & -1.519 & $-12.146^{*}$ & $\mathrm{I}(1)$ & -1.293 & $-12.632 *$ & $\mathrm{I}(1)$ \\
\hline \multirow{2}{*}{ With trend } & $-4.663^{*}$ & $-12.004 *$ & $\mathrm{I}(0)$ & $-4.760 *$ & $-12.460 *$ & $\mathrm{I}(0)$ \\
\hline & LROWD & DLROWD & Result & LROWD & DLROWD & Result \\
\hline With Constant & $-3.804 *$ & $-10.118^{*}$ & $\mathrm{I}(0)$ & $-3.804 *$ & $-10.428^{*}$ & $\mathrm{I}(0)$ \\
\hline No constant & -1.266 & $-10.208^{*}$ & $\mathrm{I}(1)$ & -1.010 & $-10.525^{*}$ & $\mathrm{I}(1)$ \\
\hline With trend & $-3.933^{*}$ & $-10.033^{*}$ & $\mathrm{I}(0)$ & $-3.974 *$ & $-10.351^{*}$ & $\mathrm{I}(0)$ \\
\hline
\end{tabular}

The results indicate that all the included variables are integrated of order zero [I(0)] or integrated of order one $[\mathrm{I}(1)]$ that is the variables are stationary at the level form or at the first difference form. The results of the unit root tests indicate that Vector Autoregressive (VAR) technique is suitable to be employed. It worth to mention that it becomes not possible to employ VAR model if there is any of the variables I(2) or higher.

VAR model turns a multiple time-series regression of each endogenous variable on lags of itself and on lags of all the other endogenous variables. VAR also fits a variant of VAR models known as VARX model that contains independent variables. VARX is the model to be employed in this study because I am interested to know the determining factors of excess reserve commercial banks holdings. VARX model can be expressed as follows:

$$
Y_{t}=\alpha_{0}+\alpha_{1} Y_{t-1}+\alpha_{2} Y_{t-2}+\ldots \ldots \ldots+\alpha_{p} Y_{t-p}+\beta X_{t}+\varepsilon_{t}
$$

Where $p$ is the lag order and $X_{t}$ is a vector of independent variables taken at time $t$ and $\beta$ is a vector of coefficients for the exogenous variables. Before turning to VARX estimation it is important to determine the 
appropriate lag order of the data. Table (3) reports the lag order selection based on different criteria, Likelihood Ratio (LR), Final Prediction Error (FPE), Akaike's Information Criterion (AIC) and Hannan and Quinn Information Criterion (HQIC) (Note 3). Lag order selection tests suggest the fourth lag as the appropriate lag order. This is consistent with Pesaran \& Pesaran (1997) who recommend the fourth lag order to be used with quarterly data.

Table 3. Lag selection

\begin{tabular}{cccccccc}
\cline { 2 - 7 } Lag & LR & df & P & FPE & AIC & HQIC \\
\hline 0 & & & & 0.10077 & 0.54143 & 0.6506 \\
1 & 0.01373 & 1 & 0.907 & 0.10424 & 0.57453 & 0.6974 \\
2 & 6.8767 & 1 & 0.009 & 0.09618 & 0.49325 & 0.6297 \\
3 & 0.12271 & 1 & 0.726 & 0.09934 & 0.52454 & 0.6747 \\
Note: * significant at $1 \%,{ }^{* *}$ significant at $5 \%, * * *$ significant at $10 \%$. & &
\end{tabular}

Having performed the unit root test and chosen the lag order, the following VARX model is estimated:

$$
\begin{aligned}
\ln \left(E R_{t}\right) & =\varphi_{0}+\partial_{1} \ln E R_{t-1}+\partial_{2} \ln E R_{t-2}+\partial_{3} \ln E R_{t-3}+\partial_{4} \ln E R_{t-4}+\varphi_{1} \ln (C / D)_{t}+\varphi_{2} \ln \left(R G D P_{t}\right) \\
& +\varphi_{3} \ln \left(N D A_{t}\right)+\varphi_{4} \ln \left(R R_{t}\right)+\varphi_{5} \ln \left(R_{t}^{T B}\right)+\varphi_{6} \ln \left(R_{t}^{I B L}\right)+\varphi_{7} \ln \left(R_{t}^{O W D}\right)+\varepsilon_{t}
\end{aligned}
$$

VARX estimation of the equation above are reported in table (4), the lag terms indicate that the excess reserve is affected in the amount of excess reserve two and four quarters in the past. The lag terms indicate the speed of excess reserve correction to the long term level. Coefficients of $\mathrm{LnER}_{\mathrm{t}-2}$ and $\operatorname{lnER} \mathrm{R}_{\mathrm{t}-4}$ is significantly and positive, that is the long term level of excess reserve reached after four quarters (one full year), the correction process occurs in two steps (every six months). The positive sign indicate that short term excess reserve is below its long term levels by .40 percent ( .20 percent each six months).

\begin{tabular}{|c|c|c|}
\hline Variables & Coefficients & Z- Statistics \\
\hline $\mathrm{LER}_{\mathrm{t}-1}$ & -.0086796 & -0.09 \\
\hline $\mathrm{LER}_{\mathrm{t}-2}$ & .2220076 & $2.52 *$ \\
\hline $\mathrm{LER}_{\mathrm{t}-3}$ & -.0481949 & -0.55 \\
\hline $\mathrm{LER}_{\mathrm{t}-4}$ & .2005024 & $2.48^{*}$ \\
\hline LCD & -1.771615 & $-2.03 *$ \\
\hline LRGDP & 1.391595 & $2.41 *$ \\
\hline LNDA & .0056444 & 0.30 \\
\hline LRR & -.2033348 & $-2.18 * *$ \\
\hline LRTB & -.1007088 & -0.24 \\
\hline LRIBL & 1.580051 & $5.53 *$ \\
\hline LROWD & 1.09545 & $4.11 *$ \\
\hline CONSTANT & -7.487871 & $-2.08 * *$ \\
\hline No. of obs.: 76 & $\mathrm{R}^{2}=0.9070$ & $\mathrm{chi}^{2}=585.0635$ \\
\hline
\end{tabular}

Table 4. VAR

Banks customers' characteristic represented by the natural logarithm of the C/D ratio has significant negative effect on the determination of the excess reserve holdings which is consistent with its expected sign. This relationship indicates that as currency to deposits holding increase excess reserve decrease because banks customers tend to keep their wealth in hand as currency rather than deposit them in the banking system.

The economic condition seems to have its expected effect on excess reserve holing. The variable $\operatorname{Ln}(\mathrm{RGDP}) \mathrm{has}$ significantly positive effect on the holding of excess reserve, that is; the belter the economic condition the higher holding of excess reserve. The impact of required reserve also comes out as expected. The variable lnRR has significant negative effect on excess reserve holdings, the increase in required reserve banks tend to reduce excess reserve to fill in the shortage occurred as a result to the higher required reserve. 
Three forms of interest rate are included $\mathrm{R}^{\mathrm{TB}}, \mathrm{R}^{\mathrm{IBL}}$ and $\mathrm{R}^{\mathrm{OWD}}$, two of them are significant and carry the expected signs. As the rate of interest on interbank loans increases the cost of this source of funds become more expensive which force banks to rely more on holding more excess reserve, and vise-a-versa. The interest rate on overnight window deposits is positively related to excess reserve holdings, as expected. The higher the return on this type of deposits carries an incentive for banks to hold more reserve. However, net domestic assets of central banks and rate of interest on treasury bills has no significant impact of commercial banks holding of excess reserve.

\subsection{Post Estimation Tests}

\subsubsection{Eigenvalue Stability Condition}

Another post estimation test is the stability of the parameter test. This test checks the eigenvalue stability condition after estimating the parameters of a VAR model. If the VAR model is stable then it is invertible and has an infinite order vector moving average representation. Hamilton (1994) and Lutkepohl (2005) show that if the modulus of each eigenvalue of the matrix A is strictly less than one, the estimated VAR is stable. Results in table (5-a) indicate that the values of the entire eigenvalues lie inside the unit circle which implies that the VARX estimation is stable. This is also reported in figure (4).

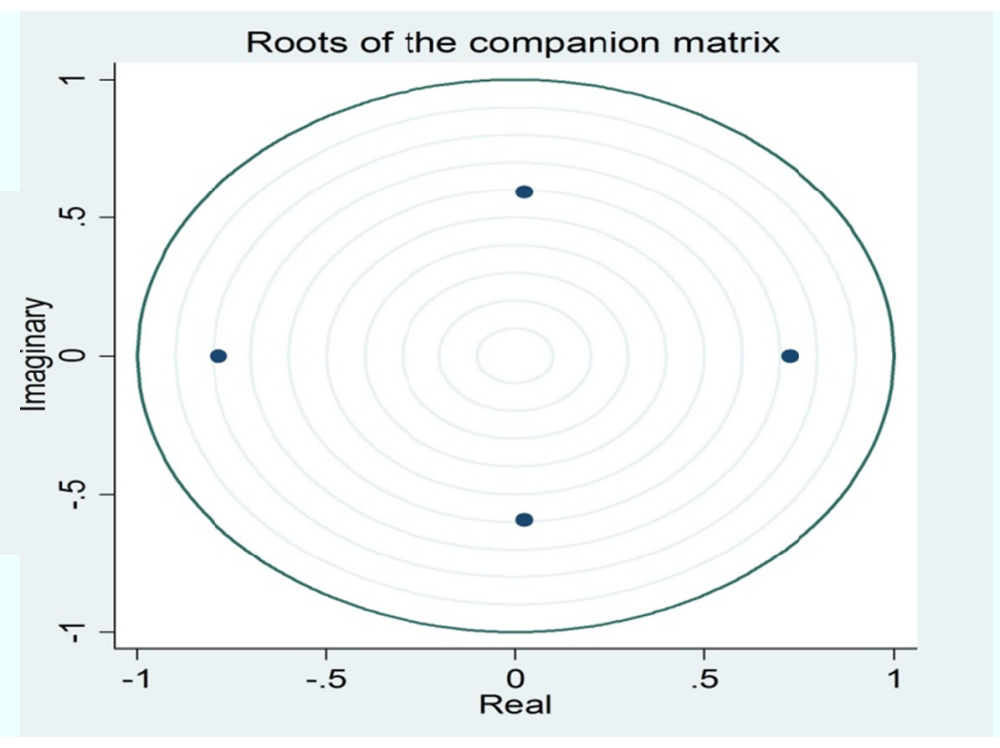

Figure 4. Stability test of VARX estimation

\subsubsection{Granger Causality Wald Tests}

After the VAR estimation I employ Granger (1969) test to check whether the exogenous variables and the lag terms granger cause the dependent variable (Table 5-b). This test's conclusion is consistent with the conclusion of the $\mathrm{R}^{2}$. The null hypothesis of this result is that the coefficients of all exogenous variables and the lag terms are jointly zero, the $\mathrm{chi}^{2}$ statistic reject the null hypothesis.

\subsubsection{Lagrange-Multiplier Test of Autocorrelation}

Johansen (1995) introduced Lagrange-multiplier (LM) test for autocorrelation in the residuals of VAR models, with a null hypothesis that there is no autocorrelation in the error of the estimation at lag j. Table (5-c) indicates that the null hypothesis at lag 4 cannot be rejected therefore there is no autocorrelation problem and no miss specification problem. 
Table 5. Post estimation tests

Panel (a): Eigenvalue stability condition

\begin{tabular}{cc}
\hline Eigenvalue & Modulus \\
\hline-.784742 & .784742 \\
.7270973 & .727097 \\
$.02448253+.5922831 \mathrm{i}$ & .592789 \\
$.02448253-.5922831 \mathrm{i}$ & .592789 \\
All the eigenvalues lie inside the unit circle. \\
VAR satisfies stability condition. \\
\hline
\end{tabular}

Panel (b): Granger causality wald tests

\begin{tabular}{ccccc}
\hline Equation & Excluded & chi2 & df & Prob $>$ chi2 \\
\hline-- & ALL & 585.06 & 11 & 0 \\
\hline
\end{tabular}

Panel (c): Lagrange-multiplier test of autocorrelation

\begin{tabular}{ccc}
\hline Lag & $\mathbf{C h i}^{\mathbf{2}}$ & Prob $>\mathbf{c h i}^{\mathbf{2}}$ \\
\hline 1 & 0.0192 & 0.88979 \\
2 & $3.7024^{* *}$ & 0.05433 \\
3 & 0.0059 & 0.93862 \\
4 & 1.3049 & 0.25332 \\
\hline
\end{tabular}

Note: * significant at $1 \%, * *$ significant at $5 \%, * * *$ significant at $10 \%$.

\section{Conclusion}

This study tends to fill a gap in the literature as it considers a small open developing country in a region that takes the attention of the world. It investigates an important issue during the period before and after the 2006/2007 financial crises. The main aim of this study is to examine the factors that determine commercial banks excess reserve holdings in Jordan banking system.

Time series techniques are used to estimate the excess reserve elastisities according to a set of variables. Vector Autoregressive with explanatory variables (VARX) is used, the dependent variable is the natural logarithm of excess reserve held in CBJ during the period of 1994-Q1 to 2012-Q4. The independent variables are classified into four groups; banks characteristics, economic condition, monetary policy and fiscal policy.

The coefficients of the excess reserve of lag terms indicate that the long term level of excess reserve reached after four quarters (one full year) and the correction process occurs in two steps (every six months). Banks customers' characteristic is significant. The empirical results indicates that as currency to deposits holding increase excess reserve decrease because banks customers tend to keep their wealth as currency in hand rather than deposit them in the banking system. The better the economic condition is the higher holding of excess reserve. Moreover, the monetary policy seems to have significant impact on banks excess reserve holdings. More specifically, the increase in the required reserve tends to reduce banks holding of excess reserve. The higher the interest rate of interbank loans the higher banks holding of excess reserve and the higher the interest of overnight window deposits the higher the excess reserve holdings. Finally, the fiscal policy concluded to be statistically insignificant.

This study can be extended in the future by considering the Middle East and North African countries where different environmental and institutional conditions can be tested. Additional future trend is to consider data at individual banks level data panel data techniques can be used.

\section{Acknowledgment}

This study was performed as a part of a scientific research project funded by the Hashemite University - Jordan. The researcher would like to introduce his thanks and appreciation to the Hashemite University for its generous financial support. 


\section{References}

Agenor, P., \& El Aynaoui, K. (2010). Excess liquidity, bank pricing rule and monetary policy. Journal of Banking \& Finance, 34(5), 923-933. http://dx.doi.org/10.1016/j.jbankfin.2009.10.003

Agenor, P., Aizenman, J., \& Hoffmaister, A. (2004). The credit crunch in East Asia: What can bank excess liquid assets tell us? Journal of International Money and Finance, 23(1), 27-49. http://dx.doi.org/10.1016/j.jimonfin.2003.08.008

Aikaeli, J. (2006). Determinants of excess liquidity in Tanzanian commercial banks. Working paper series. http://dx.doi.org/10.2139/ssrn.971750

Allen, D. S. (1998). How closely do banks manage vault cash? Federal Reserve Bank of St. Louis Review, 43-54. Retrieved from http://research.stlouisfed.org/publications/review/98/07/9807da.pdf

Anderson-Reid, K. (2011). Excess reserves in Jamaican commercial bank: The implication for monetary policy. MPRA Paper No. 43663, posted 9. Retrieved from http://mpra.ub.uni-muenchen.de/43663/

Baltensperger, E. (1974). The precautionary demand for reserves. The American Economic Review, 64, 205-210.

Baltensperger, E. (1980). Alternative approaches to the theory of the banking firm. Journal of Monetary Economics, 6, 1-37. http://dx.doi.org/10.1016/0304-3932(80)90016-1

Bindseil, U., Camba-Mendez, G., Hinch, A., \& Weller, B. (2004). Excess reserves and the implementation of monetary policy of the EBC. European Central Bank, Working Paper no361.

Civcir, I., \& Parikh, A. (1998). An error correction approach to modelling money balances and reserves. Journal of Economic Studies, 25(4), 277-295. http://dx.doi.org/10.1108/01443589810220049

Clouse, J., \& Dow, J. (1999). Fixed costs and the behavior of the federal funds rate. Journal of Banking and Finance, 23, 1015-1029. http://dx.doi.org/10.1016/S0378-4266(98)00128-9

Clouse, J., \& Dow, J. (2002). A computational model of banks' optimal reserve management policy. Journal of Economic Dynamics and Control, 26(11), 1787-1814. http://dx.doi.org/10.1016/S0165-1889(01)00010-0

Demiralp, S., \& Farley, D. (2005). Declining required reserves, funds rate volatility, and open market operations. Journal of Banking and Finance, 29(5), 1131-1152. http://dx.doi.org/10.1016/j.jbankfin.2004.05.030

Dow, J. (2001). The demand for excess reserves. Southern Economic Journal, 67(3), 685-700. http://dx.doi.org/10.2307/1061458

Frost, P. (1971). Bank's demand for excess reserves. Journal of Political Economy, 79, 805-825. http://dx.doi.org/10.1086/259789

Furfine, C. (1998). Interbank payments and the daily federal funds rate. Board of Governors of the Federal Reserve System, Finance and Economics Discussion Series, 1998-31. Retrieved from http://www.federalreserve.gov/pubs/feds/1998/199831/199831pap.pdf

Granger, C. W. J. (1969). Investigating causal relations by econometric models and cross-spectral methods. Econometrica, 37(3), 424-438. http://dx.doi.org/10.2307/1912791

Hamilton, J. D. (1994). Time series analysis. Princeton: Princeton University Press.

Heller, D., \& Lengwiller, Y. (2003). Payment obligations, reserves requirements, and the demand for central bank balance. Journal of Monetary Economics, 50, 419-432. http://dx.doi.org/10.1016/S0304-3932(03)00011-4

Johansen, S. (1995). Likelihood-based inference in cointegrated vector autoregressive models. Oxford: Oxford University Press. http://dx.doi.org/10.1093/0198774508.001.0001

Longworth, D. (1989). Optimal behavior of direct clearers in a world with zero reserve requirements. Bank of Canada, Working Paper.

Lutkepohl, H. (2005). New introduction to multiple time series analysis. New York: Springer. http://dx.doi.org/10.1007/978-3-540-27752-1

Maynard, T., \& Moore, M. (2005). The demand for excess liquid assets in barbados. Research Department, Central Bank of Barbados. Retrieved http://centralbank.org.bb/webcbb.nsf/WorkingPapers/E2D716A323F38683042577F2005E7C9D/\$FILE/WP 2005-21.pdf

Murta, F., \& Gracia, A. (2009). The demand for excess reserves in the Euro Area and how the current credit 
crisis influences it. GEMF-Grupo de Estudos Monetários e Financeiros, Faculdade de Economia da Universidade de Coimbra, February. Retrieved from http://gemf.fe.uc.pt/workingpapers/abstracts/2010/resumo2010_01.htm

Nautz, D. (1998). Bank's demand for reserves when future monetary policy in uncertain. Journal of Monetary Economics, 42, 161-183. http://dx.doi.org/10.1016/S0304-3932(98)00012-9

Orr, D., \& Mellon, W. G. (1961). Stochastic reserves losses and expansion of bank credit. American Economic Review, 51(4), 614-623. Retrieved from http://www.jstor.org/stable/1812788

Pesaran, H., \& Pesaran, B. (1997). Working with Microfit 4.0. Oxford: Oxford University Press.

Poole, W. (1968). Commercial bank reserve management in a stochastic model. Journal of Finance, 23(5), 769791. http://dx.doi.org/10.1111/j.1540-6261.1968.tb00316.x

Santomero, A. M. (1984). Modelling a banking firm: A survey. Journal of Money, Credit and Banking, 16(4), 576-602. http://dx.doi.org/10.2307/1992092

Saxegaard, M. (2006). Excess liquidity and the effectiveness of monetary policy: Evidence from Sub-Saharan Africa. Working Paper 06/115, International Monetary Fund. Retrieved from http://www.imf.org/external/pubs/ft/wp/2006/wp06115.pdf

Selgin, G. (2001). In-Concert overexpansion and the precautionary demand for bank reserve. Journal of Money, Credit, and Banking, 33(2), 294-300. http://dx.doi.org/10.2307/2673887

Talasli, A. (2010). The demand for excess reserves in Turkey. Banks and Bank Systems, 5(4), 47-53. Retrieved from http://businessperspectives.org/journals_free/bbs/2010/BBS_en_2010_4_Talash.pdf

\section{Notes}

Note 1. According to central bank of Jordan law article 42, (1).

Note 2. CBJ website publications: www.cbj.gov.jo .

Note 3. These tests are performed according to the definition of Lutkepohl (2005).

\section{Copyrights}

Copyright for this article is retained by the author(s), with first publication rights granted to the journal.

This is an open-access article distributed under the terms and conditions of the Creative Commons Attribution license (http://creativecommons.org/licenses/by/3.0/). 